\title{
Protesters ask for more
}

\section{Washington}

Two hundred police officers wearing riot helmets and rubber gloves were called in to protect the US National Institutes of Health (NIH) last week as a crowd of nearly 1,000 activists massed on its campus demanding an acceleration in AIDS research, increased access to experimental drugs for minority groups and more vigorous research into AIDSrelated opportunistic infections.

About 60 demonstrators were arrested on the campus for attempting to break into buildings and a further 21 were arrested while staging a sit-in in the office of Daniel Hoth, director of the division of AIDS for the National Institute of Allergy and Infectious Diseases (NIAID). But despite fervid chants of "We want a cure, this is a war" and "storm the NIH", there were no reports of serious injuries or damage to property, with most demonstrators being content to wave placards or adorn NIH trees with symbolic red tape.

Anthony Fauci, director of NIAID, described the protest as "street theatre" - interesting, but unhelpful. "It was rather inappropriate that they should demonstrate against the very institution that is trying to help them", he said.

Organized by the militant US AIDS activist organization ACT-UP, the demonstration marks the latest battle in an increasingly emotional campaign by activists to influence the course of AIDS research. Mark Harrington, ACT-UP's spokesman on research policy, claims that the demonstration was precipitated by a growing feeling among activists - that $\mathrm{NIH}$ policies on drug development are "too conservative and unimaginative", and that there are "too many drugs coming out of the test-tube but not getting into bodies". The last straw, says Harrington, was hearing that the initiation of new clinical trials of drugs would be delayed by nine months because the database was switched from the Research Triangle Institute at North Carolina to the Statistical and Data Analysis Center at Harvard Medical School.

But Fauci dismisses that claim as one of a number of "absolutely untrue" allegations - "the same rate and pace and number of trial protocols have been put into effect" this year as were executed last year, he says.

NIAID's policies on research and clinical trials have been bitterly attacked in documents released both independently by ACT-UP and jointly by 25 different AIDS activist organizations, ACT-UP among them. One of the key criticisms is that NIAID's clinical trials, which at present enrol only 1 per cent of US AIDS patients, are too limited and exclude minority groups such as children and pregnant women. Fauci, however, says that the activists fail to acknowledge that the need for increased medical services for minority groups in the United States is part of a "general problem in the medicalcare delivery system". He argues that NIAID has already introduced a host of measures designed to help increase the accessibility of clinical trials to minority groups and points out that 15 of its trial units are now devoted to paediatrics.

The documents also claim that NIHdirected research into the many opportunistic infections that afflict AIDS patients is inadequate, particularly as some AIDS patients are now living longer because of AZT. Fauci says that NIAID is "clearly aware of the fact that opportunistic infection research has not proceeded as quickly and as intensively as research on HIV anti-retroviral drugs" and has already taken steps to "correct that" by expanding its trials of treatments for opportunistic infections. The number of patients involved in such trials has more than tripled in the past year, he says.

\section{One down, one to go}

\section{London}

THE UK agriculture ministry has announced that a 15-month-old cow suspected of having bovine spongiform encephalopathy (see Nature 345, 280; 24 May 1990) did not have the disease. But the ministry says that its Central Veterinary Laboratory at Weybridge is still examining a second suspected case in a cow born after the ban on cattle feed containing ruminant tissues.

Peter Aldhous

The other main allegation is that in setting their research priorities some NIH researchers are being swayed by the need to please the drug companies that top up their coffers. The activist documents demand that principal AIDS researchers be bound to disclose their financial ties just as members of FDA advisory committees are. But Fauci says the demand is unnecessary - AIDS researchers must already divulge their financial interests, and the staff of NIAID, who ultimately decide which drugs should be tested, are forbidden to have any ties to industry.

David Concar EC SCIENCE

\section{Worries over Framework}

\section{London \& Munich}

THE emergence of the European Communities' (EC) third Framework research and development programme last month, with a shift towards more basic science, has provoked apprehension in the UK research councils that British research will suffer as resources switch to EC projects. The new Framework Programme is set to run from 1990 to 1994 and has a budget of 5,700 million $\mathrm{ECU}(1 \mathrm{ECU}=£ 0.72)$, an increase of over 300 million ECU over the previous five-year programme. But very little of the new programme's budget will be spent until 1991, and the previous programme runs into 1992.

In Britain, the Treasury adjusts the budgets of spending ministries to account for the United Kingdom's contributions to (and returns from) the EC. This 'attribution' depends on secret negotiations before the annual autumn statement on public expenditure. Similar arrangements exist in other member states, including West Germany, but they are less rigid. "Our contributions to the EC have been growing for the past 10 years and BMFT [research ministry] budgets have never been cut", says a BMFT spokesman.

'Attribution' worries the UK research councils because as the new Framework programme increases support for basic research, the Department of Education and Science (DES)'s budget, from which research councils are funded, may be squeezed. A total of 518 million ECU is planned for basic science under the new Framework programme, increased from 180 million ECU spent from 1988-92.

A Science and Engineering Research Council (SERC) memorandum to the House of Commons Education, Science and Arts Committee says that it is difficult for SERC to assess EC research programmes "without knowing whether resources... would come from the [DES] science budget". Dai Rees, secretary of the Medical Research Council, fears that the DES 'flexibility margin' - a fund of about 15 million ECU kept back for priority research arising after the rest of the science budget is allocated - may be swallowed up by attribution against EC research spending. Rees is critical of EC medical science, also set to grow under the new Framework programme. A tendency to "throw money at things to look good" exists in the EC, he says, "which goes against the grain when you're turning down good projects".

Sir Peter Swinnerton-Dyer, chairman of CODEST, the committee that oversees EC support for basic science, says Rees's concern over attribution against the DES budget is valid "in principle". But he thinks Rees overestimates the problem. Eileen Buttle, secretary of the Natural Environment Research Council, says the research councils must ensure that their views are heard when EC research programmes are drawn up. 